\title{
Serum Antioxidant Status and Some Selected Trace Metal Levels in Patients with Cervical Intraepithelial Neoplasm in Benin City, Nigeria
}

\author{
*1,2 ATOE, K; ${ }^{3}$ PETER, OO \\ ${ }^{I}$ Department of Chemical Pathology, Edo University, Iyamho, Edo State, Nigeria \\ ${ }^{2}$ Applied Environmental Bioscience and Public Research Group, University of Benin, Benin City, Nigeria \\ ${ }^{3}$ Department of Obstetrics and Gynecology, University of Benin Teaching Hospital, Benin City, Nigeria \\ *Corresponding Author Email: atoe.kenneth@edouniversity.edu.ng
}

\begin{abstract}
Antioxidants are important in the detoxification of free radicals, which are the hazardous derivatives of metabolic processes in the body. However, the mop up of free radicals in the prevention and management of cervical intraepithelial neoplasm is not clear. This study presented an assessment of the status of catalase (CAT), glutathione peroxidase (GPx), superoxide dismutase (SOD), total antioxidant capacity (TAC) and some trace metals (Ca, $\mathrm{Mg}, \mathrm{Cu}$ and $\mathrm{Zn}$ ) in women diagnosed with Cervical Intraepithelial Neoplasm (CIN) lesions. The study was carried out at the Department of Obstetrics and Gynaecology, University of Benin Teaching Hospital Benin City and Department of Chemical Pathology, Edo University Iyamho, Edo state Nigeria. Study participants were grouped into two; those with CIN lesions $(n=144)$ and the control $(n=53)$. Venous blood was obtained from participants and serum antioxidant levels were determined using standardized laboratory methods. Results showed that CAT levels increased significantly from $23.88 \mathrm{u} / \mu \mathrm{l} / \mathrm{min}$ in the control group to $31.79 \mathrm{u} / \mu \mathrm{l} / \mathrm{min}$ in CIN. The incidence of cervical intraepithelial neoplasm lesions did not significantly affect total antioxidant capacity (TAC) of the study population $(2.43-2.70 \mathrm{mM}, \mathrm{P}>0.05)$. There were minimal increases in antioxidant status between the control and $\mathrm{CIN}$ groups respectively $(\mathrm{P}>0.05)$. Cu was implicated as the only trace metal within the CIN group without significant correlation to the antioxidants investigated.
\end{abstract}

DOI: https://dx.doi.org/10.4314/jasem.v23i8.11

Copyright: Copyright (C) 2019 Atoe and Peter. This is an open access article distributed under the Creative Commons Attribution License (CCL), which permits unrestricted use, distribution, and reproduction in any medium, provided the original work is properly cited.

Dates: Received: 30 June 2019; Revised: 30 July 2019; Accepted 21 August 2019

Keywords: Epithelial cell, cervical cancer, neoplasm, antioxidant status

Free radicals are thought to contribute and/or trigger the onset of cancers. Antioxidants have been reported to reduce these radicals from the body system (Shannon et al., 2002). The interaction between free radicals and antioxidants in the serum of patients with premalignant conditions is important in monitoring the advancement or treatment of the condition. GarciaClosas and colleagues in 2005 concluded in their research that the likely protective effect against cervical neoplasia was afforded by folate, retinol, vitamin $\mathrm{E}$, vitamin $\mathrm{C}$ and lycopene. Cervical Intraepithelial Neoplasm (CIN) embraces all grades of dysplasia in situ and epithelial aberrations of the cervix. (Munoz et al., 2002) It is an antecedent lesion for squamous cell carcinoma of the uterine cervix (van Dam et al., 2018). Cervical intraepithelial neoplasm progresses in 3 stages as CIN 1, CIN 2 and CIN 3, depending on the degree of cellular stratification and abnormality within the epithelium (Bais, et al., 2005). Risk factors in CIN include several sexual partners, HPV infection, lower genital tract neoplasia, cigarette smoking, immuno-deficiency, multiparity and long term oral contraceptive pill uses (Parkin, 2001). These stress factors may cause the accumulation of free radicals which lead to ageing of the body cells and reduced immunity. Certain lifestyle habits have also been associated with elevated levels of reactive oxygen species (ROS) in the body system. Cigarette smoking initiates lipid peroxidation and causes endothelial cell dysfunction (Walboomers et al., 1999). Studies revealed that nutritional factors may play an important role in the development and progression of cervical cancer (Potischman and Brinton, 1996; Tomita et al., 2010). Epidemiological and analytical studies have been conducted to investigate the relationship between antioxidant nutrients and cervical cancer (Wideroff et al., 1998). This interaction between antioxidant nutrients and abnormal cell metabolism remains complicated and should be properly studied. Over the preceding two decades, epidemiological findings indicated that higher ingestion of dietary antioxidants and increased serum concentrations of antioxidant micronutrients may be associated with a reduced risk of several cancers, including cervical cancer (Michels et al., 2001). These cancers are thought to be mostly caused or assisted by ROS, which are dangerous by-products of metabolic processes in the body. Antioxidants serve 
as scavengers of ROS. In healthy systems, usually used as control groups in studies like this, ROS and antioxidants are in a state of balance (Kim et al., 2002). However, when the quantity of ROS exceeds those of antioxidants, the system enters a state of oxidative stress (Ziegler, 1991). Antioxidative enzymes, such as superoxide dismutase (SOD), catalase (CAT), glutathione peroxidase (GPX), glutathione reductase (GR) and glutathione-Stransferase (GST), maintain redox balance. Their activities can be used to estimate the oxidative defense mechanism capacity of an individual. Antioxidative enzymes may also inhibit both the initiation and promotion of carcinogenesis (Jelic et al., 2018). Researchers have shown that the HPV is involved in cervical cancer. The mechanism by which HPV acts is by damaging the DNA. Other studies have shown the potential of ROS in damaging DNA, thereby causing mutations. There are evidences that both HPV and ROS have same effect with regards to cervical cancer (Lee et al., 2005), hence the assessment of the status of serum antioxidants and trace metals in the screening, progression or regression of patients with premalignant cervical lesions is important. This study aim was to examine the status of catalase (CAT), glutathione peroxidase (GPx), superoxide dismutase (SOD), total antioxidant capacity (TAC) and some trace metals ( $\mathrm{Ca}, \mathrm{Mg}, \mathrm{Cu}$ and $\mathrm{Zn}$ ) in women diagnosed with Cervical Intraepithelial Neoplasm (CIN).

\section{MATERIALS AND METHODS}

One hundred and ninety-seven (197) participants were recruited for this study at the Urogynaecology and Gynae-oncology Unit of the Department of Obstetrics and Gynaecology, University of Benin Teaching Hospital (UBTH) from August 2017 to January 2019. Study participants were grouped into two; those with CIN lesions $(n=144)$ and the control $(n=53)$ (Plates 1 - 4). The biochemical analysis of the research participants was done at the Metabolic Research Unit of the Department of Chemical Pathology, Edo University Iyamho, Edo state, Nigeria. Cases included patients with histological diagnosis of cervical intraepithelial neoplasm and abnormal Pap smear referred from Gynaecology Clinic, General Practice Clinic, Community Development Clinic in UBTH and also referrals for Colposcopy from private hospitals in Benin City. Control participants were selected from the Gynaecology clinic of UBTH and were patients with normal Colposcopy who matched the case for age and parity. Venous blood was obtained from participants and serum catalase (CAT), glutathione peroxidase (GPx), superoxide dismutase (SOD), total antioxidant capacity (TAC) and some trace metals ( $\mathrm{Ca}, \mathrm{Mg}, \mathrm{Cu}$ and $\mathrm{Zn}$ ) levels were determined using standard laboratory methods.
CAT determination: CAT was determine using colorimetric method. Catalase reacted with a known quantity of hydrogen peroxide $\left(\mathrm{H}_{2} \mathrm{O}_{2}\right)$. The reaction was stopped after one minute with catalase inhibitor. In the presence of peroxidase, remaining $\mathrm{H}_{2} \mathrm{O}_{2}$ reacted with 3, 5- dichloro-Z-hydroxybenzene sulfonic acid (DHBS) and 4 aminoantipyrene, AAP to form a chromophore with a color intensity inversely proportional to the amount of catalase in the original sample (Aebi, 1984).

GPx determination: This was carried out using spectrophotometric method. Glutathione peroxidase catalysed the oxidation of glutathione by cumene hydroperoxide. The oxidized glutathione was converted to the reduced form in the presence of glutathione reductase and NADPH. The NADPH was oxidized to NADP+ simultaneously. The decrease in absorbance at $340 \mathrm{~nm}$ was then measured (Magnani et al., 2000).

SOD determination: Superoxide dismutase was determined using pyrogallol autoxidation method. The enyzme superoxide dismutase has the ability to inhibit the autoxidation of pyrogallol. The autoxidation of pyrogallol in the presence of EDTA at a $\mathrm{pH}$ of 8.2 is $50 \%$. The principle of this method is based on the competition between the pyrogallol autoxidation by $\mathrm{O}_{2}$ and the dismutation of this radical by SOD (Marklund and Marklund, 1974).

TAC determination: Total antioxidant capacity was determined using spectrophotometric technique which relied on the combined action of the antioxidants provided by the sample as standard. This standard acted to reduce $\mathrm{Cu}^{++}$to $\mathrm{Cu}^{+}$. This reduced form of copper selectively formed a 2:1 complex with the chromogenic reagent. This complex is stable and has an absorption maximum at 490nM (Magnani et al., 2000).

Trace metals: The serum levels of selected trace metals were determined spectrophotometrically. Randox, Teco, and Fotress diagnostic commercial kits were used, and standard operating procedures was followed (Henry, 1984).

\section{RESULTS AND DISCUSSION}

There were 144 participants in the cervical intraepithelial neoplasm (CIN) group as compared to 53 participants in the control group (Table 1). The CIN group which comprised of 144 women had 45 individuals who were at stage $1 \mathrm{CIN}, 49$ at stage $2 \mathrm{CIN}$ and 50 women who had CIN stage 3 . However, there were no candidates implicated for CIN in the control 
group. According to the age factor, $11 \%$ of the CIN group consist of the 31-40 age category as compared to the $38.9 \%$ that belonged to the $51-60$ years age category within the CIN group. On the basis of conception, $98 \%$ of the CIN group conceived successfully. However, $1 \%$ each of the CIN group had 2 and 7 unsuccessful conceptions respectively. Cervical cancer is thought to be mediated by Human Papilloma Virus (HPV) but past studies have revealed the role of oxidative stress in cervical cancer (Smita et al., 2007). However, the toxic effects of free radicals causing oxidative stress are expected to be protected by a defense system such as antioxidant vitamins, minerals, and antioxidant enzymes (WHO, 2002). The findings in this study assessed the status of CAT, GPX,
SOD and TAC including some trace metals; $\mathrm{Ca}, \mathrm{Mg}$, $\mathrm{Cu}$, and $\mathrm{Zn}$ in women expected to have various level of oxidative stress due to their CIN status. The serum antioxidant status and trace metal levels in the study participants were also presented (Table 2). There were significant differences in serum catalase (CAT) level between the normal and the CIN groups $(\mathrm{P}<0.05)$. CAT levels increased significantly from $23.88 \mathrm{u} / \mu 1$ to $31.79 \mathrm{u} / \mu \mathrm{l}$. However, there were minimal increases in SOD levels between the normal and the CIN groups $(\mathrm{P}>0.05)$. The incidence of cervical intraepithelial neoplasm lesions did not significantly affect total antioxidant capacity (TAC) of the study population (2.70 mM - $2.43 \mathrm{mM}, \mathrm{P}>0.05)$.

Table 1: Socio-demographic characteristics of the study population

\begin{tabular}{|c|c|c|c|c|c|c|c|c|}
\hline & & \multicolumn{2}{|c|}{$\begin{array}{l}\text { CIN group } \\
(\mathrm{n}=144)\end{array}$} & \multicolumn{3}{|c|}{$\begin{array}{l}\text { Control group Df } \\
(\mathbf{n}=\mathbf{5 3})\end{array}$} & \multirow[t]{2}{*}{$\mathrm{X}^{2}$} & \multirow[t]{2}{*}{$\begin{array}{l}\mathrm{p}- \\
\text { value }\end{array}$} \\
\hline & & (n) & $(\%)$ & (n) & $(\%)$ & & & \\
\hline CIN.Staus & $\begin{array}{l}\text { Normal } \\
\text { Stage } 1 \\
\text { Stage } 2 \\
\text { Stage } 3\end{array}$ & $\begin{array}{l}0 \\
45 \\
49 \\
50\end{array}$ & $\begin{array}{l}0.0 \\
22.8 \\
24.9 \\
25.4\end{array}$ & $\begin{array}{l}53 \\
0 \\
0 \\
0\end{array}$ & $\begin{array}{l}26.9 \\
0.0 \\
0.0 \\
0.0\end{array}$ & 3.0 & 0.463 & 0.925 \\
\hline Agegroup & $\begin{array}{l}31-40 \mathrm{yrs} \\
41-50 \mathrm{yrs} \\
51-60 \mathrm{yrs} \\
61-70 \mathrm{yrs} \\
>70 \mathrm{yrs}\end{array}$ & $\begin{array}{l}17 \\
32 \\
56 \\
10 \\
29\end{array}$ & $\begin{array}{l}11.8 \\
22.2 \\
38.9 \\
6.9 \\
20.1\end{array}$ & $\begin{array}{l}15 \\
10 \\
20 \\
8 \\
0\end{array}$ & $\begin{array}{l}28.3 \\
18.9 \\
37.7 \\
15.1 \\
0.0\end{array}$ & 4.0 & 5.784 & 0.216 \\
\hline $\begin{array}{l}\text { Educational } \\
\text { Stage }\end{array}$ & $\begin{array}{l}\text { Primary Edv. } \\
\text { Secondary Edv. } \\
\text { Tertiary Edv. }\end{array}$ & $\begin{array}{l}58 \\
16 \\
70\end{array}$ & $\begin{array}{l}40.3 \\
11.1 \\
48.6\end{array}$ & $\begin{array}{l}5 \\
26 \\
22\end{array}$ & $\begin{array}{l}9.4 \\
49.1 \\
41.5\end{array}$ & 2.0 & 2 & 0.368 \\
\hline Parity & $\begin{array}{l}1.00 \\
2.00 \\
3.00 \\
4.00 \\
5.00 \\
6.00 \\
7.00 \\
8.00 \\
11.00\end{array}$ & $\begin{array}{l}0 \\
6 \\
24 \\
38 \\
32 \\
19 \\
0 \\
22 \\
3\end{array}$ & $\begin{array}{l}0.0 \\
4.2 \\
16.7 \\
26.4 \\
22.2 \\
13.2 \\
0.0 \\
15.3 \\
2.1\end{array}$ & $\begin{array}{l}9 \\
0 \\
11 \\
17 \\
6 \\
8 \\
2 \\
0 \\
0\end{array}$ & $\begin{array}{l}17.0 \\
0.0 \\
20.8 \\
32.1 \\
11.3 \\
15.1 \\
3.8 \\
0.0 \\
0.0\end{array}$ & 8.0 & 11.501 & 0.175 \\
\hline $\begin{array}{l}\text { Unsuccessful } \\
\text { conception }\end{array}$ & $\begin{array}{l}.00 \\
1.00 \\
2.00 \\
7.00\end{array}$ & $\begin{array}{l}142 \\
0 \\
1 \\
1\end{array}$ & $\begin{array}{l}98.6 \\
0.0 \\
.7 \\
.7\end{array}$ & $\begin{array}{l}49 \\
4 \\
0 \\
0\end{array}$ & $\begin{array}{l}92.5 \\
7.5 \\
.0 \\
.0\end{array}$ & 3.0 & 4.386 & 0.223 \\
\hline $\begin{array}{l}\text { Marriage } \\
\text { type }\end{array}$ & $\begin{array}{l}\text { Monogamy } \\
\text { Polyganry }\end{array}$ & $\begin{array}{l}127 \\
17\end{array}$ & $\begin{array}{l}88.2 \\
11.8\end{array}$ & $\begin{array}{l}37 \\
16\end{array}$ & $\begin{array}{l}69.8 \\
30.2\end{array}$ & 1.0 & 2.4 & 0.121 \\
\hline $\begin{array}{l}\text { Smoking } \\
\text { habit }\end{array}$ & $\begin{array}{l}\text { Smokers } \\
\text { Non Smokers }\end{array}$ & $\begin{array}{l}46 \\
98\end{array}$ & $\begin{array}{l}31.9 \\
68.1\end{array}$ & $\begin{array}{l}7 \\
46\end{array}$ & $\begin{array}{l}13.2 \\
86.8\end{array}$ & 1.0 & 2.4 & 0.121 \\
\hline $\begin{array}{l}\text { History of } \\
\text { usage of } \\
\text { OCP }\end{array}$ & $\begin{array}{l}\text { No history } \\
<1 \text { yr } \\
1-3 \text { yrs } \\
4-6 \text { yrs } \\
>6 \text { yrs }\end{array}$ & $\begin{array}{l}66 \\
68 \\
4 \\
0 \\
6 \\
\end{array}$ & $\begin{array}{l}45.8 \\
47.2 \\
2.8 \\
0.0 \\
4.2 \\
\end{array}$ & $\begin{array}{l}24 \\
9 \\
5 \\
12 \\
3 \\
\end{array}$ & $\begin{array}{l}45.3 \\
17.0 \\
9.4 \\
22.6 \\
5.7 \\
\end{array}$ & 4.0 & 5.564 & 0.234 \\
\hline
\end{tabular}

The bivariate relationship between serum antioxidants and serum level of trace metals in CIN group against the control group showed that $\mathrm{Mg}$ and $\mathrm{Ca}$ were positively correlated to glutathione peroxidase (GPX) ( $\mathrm{r}=0.384$ and $\mathrm{r}=0.446$ respectively) in CIN participants $(\mathrm{P}<0.01)$. Whereas, there were no significant correlations between these two metals and GPx in the control group $(r=-0.096$ and $r=0.164, P$ $>0.05$ respectively). $\mathrm{Mg}$ fairly correlated positively with SOD in the CIN group $(\mathrm{r}=0.264, \mathrm{P}<0.01)$; however, SOD and $\mathrm{Mg}$ were not significantly correlated in the control group $(\mathrm{r}=-0.194, \mathrm{P}>0.01)$. 
Table 2: Serum antioxidant status and elemental composition in the study participants.

\begin{tabular}{|c|c|c|c|c|c|c|c|c|c|}
\hline & (n) & $\begin{array}{l}\text { CAT } \\
(\mu \mathrm{mol} / \mathrm{ml} / \mathrm{min})\end{array}$ & $\begin{array}{l}\text { SOD } \\
(\mathrm{U} / \mathrm{mL})\end{array}$ & $\begin{array}{l}\text { GPX } \\
(\mathrm{U} / \mathbf{L})\end{array}$ & $\begin{array}{l}\text { TAC } \\
(\mathbf{m M})\end{array}$ & $\begin{array}{l}\text { Mg } \\
(\mathrm{mg} / \mathrm{dl})\end{array}$ & $\begin{array}{l}\mathrm{Ca} \\
(\mathrm{mmol} / \mathrm{L})\end{array}$ & $\begin{array}{l}\mathrm{Cu} \\
(\mu \mathrm{g} / \mathrm{dl})\end{array}$ & $\begin{array}{l}\mathrm{Zn} \\
(\mu \mathrm{g} / \mathrm{dl})\end{array}$ \\
\hline Normal & 53 & $23.88 \mathrm{a}$ & $1.08 \mathrm{a}$ & $6.71 \mathrm{a}$ & $2.17 \mathrm{a}$ & $2.50 \mathrm{a}$ & $2.04 \mathrm{~b}$ & 56.01ab & $127.02 \mathrm{a}$ \\
\hline Level 1 & 45 & $27.29 \mathrm{~b}$ & $1.30 \mathrm{ab}$ & $7.80 \mathrm{a}$ & $2.39 \mathrm{a}$ & $2.48 \mathrm{a}$ & $2.11 \mathrm{c}$ & $58.23 \mathrm{~b}$ & $137.03 b$ \\
\hline Level 2 & 49 & $27.67 b$ & $1.40 \mathrm{~b}$ & 7.96a & $2.48 \mathrm{a}$ & $2.37 \mathrm{a}$ & $1.97 \mathrm{a}$ & $52.23 \mathrm{ab}$ & $125.13 \mathrm{a}$ \\
\hline Level 3 & 50 & $31.79 \mathrm{c}$ & $1.49 \mathrm{~b}$ & $9.16 \mathrm{~b}$ & $2.43 \mathrm{a}$ & $2.49 a$ & $2.05 \mathrm{~b}$ & $49.59 \mathrm{a}$ & $135.40 \mathrm{~b}$ \\
\hline F- statistics & & 17.05 & 2.78 & 5.70 & 1.35 & 13.73 & 11.12 & 2.61 & 6.89 \\
\hline $\mathrm{p}$-value & & $<0.001$ & 0.042 & 0.001 & 0.251 & 0.067 & $<0.001$ & 0.053 & 0.001 \\
\hline
\end{tabular}

Table 3: Comparison of bivariate association between serum antioxidant status and elemental composition of CIN group against the control group.

\begin{tabular}{|c|c|c|c|c|c|c|c|c|c|}
\hline & & \multicolumn{4}{|c|}{ Correlations - CIN } & \multicolumn{4}{|c|}{ Correlations - Control } \\
\hline & & Mg & $\mathbf{C a}$ & $\mathbf{C u}$ & $\mathbf{Z n}$ & Mg & $\mathbf{C a}$ & $\mathbf{C u}$ & $\mathbf{Z n}$ \\
\hline \multirow{2}{*}{ Catalase } & $\mathrm{r}$ & -0.13 & -0.047 & 0.053 & -0.086 & 0.169 & 0 & 0.057 & $.349^{*}$ \\
\hline & $\mathrm{p}$ & 0.122 & 0.573 & 0.531 & 0.303 & 0.227 & 0.995 & 0.687 & 0.01 \\
\hline \multirow{2}{*}{ SOD } & $\mathrm{r}$ & $.264^{* *}$ & 0.059 & 0.148 & -0.022 & -0.194 & 0.042 & -0.049 & -0.246 \\
\hline & $\mathrm{p}$ & 0.001 & 0.484 & 0.078 & 0.795 & 0.164 & 0.763 & 0.729 & 0.076 \\
\hline \multirow{2}{*}{ GPX } & $\mathrm{r}$ & $.384^{* *}$ & $.446^{* *}$ & -0.161 & $.216^{* *}$ & -0.096 & 0.164 & $.340^{*}$ & $-.350^{*}$ \\
\hline & $\mathrm{p}$ & 0 & 0 & 0.054 & 0.009 & 0.493 & 0.24 & 0.013 & 0.01 \\
\hline \multirow{2}{*}{ TAC } & $\mathrm{r}$ & 0.15 & $.192^{*}$ & 0.107 & $-.332^{* *}$ & 0.253 & 0.15 & $.274^{*}$ & 0.049 \\
\hline & $\mathrm{p}$ & 0.073 & 0.021 & 0.201 & 0 & 0.067 & 0.285 & 0.047 & 0.729 \\
\hline
\end{tabular}

Table 4: Distribution of Comparison antioxidant status and elemental composition of the study participants with history of smoking.

\begin{tabular}{llllllll}
\hline Antioxidant/elements & Smokers & $\mathbf{N}$ & Mean & SD & p-value & $\begin{array}{c}\text { 95\%CI } \\
\text { (lower) }\end{array}$ & $\begin{array}{c}\text { 95\%CI } \\
\text { (upper) }\end{array}$ \\
\hline $\mathrm{CAT}(\mu \mathrm{mol} / \mathrm{ml} / \mathrm{min})$ & Control & 7 & 20.46 & 9.47 & 0.001 & -13.09 & -3.41 \\
& $\mathrm{CIN}$ & 46 & 28.70 & 5.30 & & & \\
$\mathrm{SOD}(\mathrm{U} / \mathrm{ml})$ & Control & 7 & 0.96 & 0.46 & 0.001 & -0.89 & -0.26 \\
& CIN & 46 & 1.53 & 0.38 & & & \\
$\mathrm{GPx}(\mathrm{U} / \mathrm{L})$ & Control & 7 & 5.40 & 4.49 & 0.007 & -5.72 & -0.98 \\
& CIN & 46 & 8.75 & 2.63 & & & \\
$\mathrm{TAC}(\mathrm{mM})$ & Control & 7 & 2.61 & 1.50 & 0.483 & -0.41 & 0.86 \\
& CIN & 46 & 2.39 & 0.63 & & & \\
$\mathrm{Mg}(\mathrm{mg} / \mathrm{dl})$ & Control & 7 & 2.53 & 0.13 & 0.003 & 0.05 & 0.21 \\
& CIN & 46 & 2.40 & 0.10 & & & \\
$\mathrm{Ca}(\mathrm{mmol} / \mathrm{l})$ & Control & 7 & 2.03 & 0.05 & 0.339 & -0.22 & 0.08 \\
& CIN & 46 & 2.10 & 0.19 & & & \\
$\mathrm{Cu}(\mu \mathrm{g} / \mathrm{dl})$ & Control & 7 & 83.91 & 17.78 & $<0.001$ & 17.69 & 38.39 \\
& CIN & 46 & 55.87 & 11.87 & & & \\
$\mathrm{Zn}(\mu \mathrm{g} / \mathrm{dl})$ & Control & 7 & 131.40 & 16.31 & 0.052 & -0.08 & 16.97 \\
& CIN & 46 & 122.96 & 9.42 & & & \\
\hline
\end{tabular}

The antioxidant and trace metal status of participants with a positive history of smoking for both the control and CIN groups were presented in Table 4. Serum levels of CAT and SOD of participants within the CIN group were significantly higher compared to the control group. Serum CAT level was $20.46 \mathrm{u} / \mathrm{ml} / \mathrm{min}$ in control and $28.70 \mathrm{u} / \mathrm{ml} / \mathrm{min}$ in CIN group while serum SOD level was $0.96 \mathrm{u} / \mathrm{ml}$ in control and 1.53 $\mathrm{u} / \mathrm{ml}$ in CIN group $(\mathrm{P}<0.001)$. Though, the level of total antioxidant capacity (TAC) was slightly more in the control group. However, the observed mean difference of the TAC status among participants with smoking history were not statistically significant; 2.61 $\mathrm{mM}$, in the control group and $2.39 \mathrm{mM}$ in CIN $(\mathrm{P}>0.001)$. Participants with a positive history of smoking in the control group had serum $\mathrm{Cu}$ level of $83.91 \mu \mathrm{g} / \mathrm{dl}$, whereas serum $\mathrm{Cu}$ level was $55.87 \mu \mathrm{g} / \mathrm{dl}$ in the CIN group. Individuals in the control group also had higher serum $\mathrm{Zn}$ level of $131.40 \mu \mathrm{g} / \mathrm{dl}$ compared to $122.96 \mu \mathrm{g} / \mathrm{dl}$ in the CIN group. The only trace metal with serum level significantly different among smokers in control and CIN group was $\mathrm{Cu}(83.91 \mu \mathrm{g} / \mathrm{dl}$ in control as against $55.87 \mu \mathrm{g} / \mathrm{dl}$ in CIN group) p-value $<0.001$.

The increasing serum catalase (CAT) status of the under studied individuals with Cervical Intraepithelial Neoplasm (CIN) implies that more of the enzyme was required by the CIN participants to protect their system from the redox imbalance created due to progress of the premalignant lesion. An increase in CAT activities has been reported in breast cancer, uterine cancer as well as cervical cancer (Kumaraguruparan et al., 2002; Wozniak et al., 2007). 
The present study agrees with these reports. However, the status of the other serum antioxidants examined (GPx, SOD and TAC) in CIN patients were not significantly different from the levels in the serum of the healthy women. This may probably be due to the similar dietary pattern; environmentally induced physiology and lifestyle of the subjects in this study given that all participants reside in Benin City, and may likely depend on diets of relatively similar antioxidant contents.

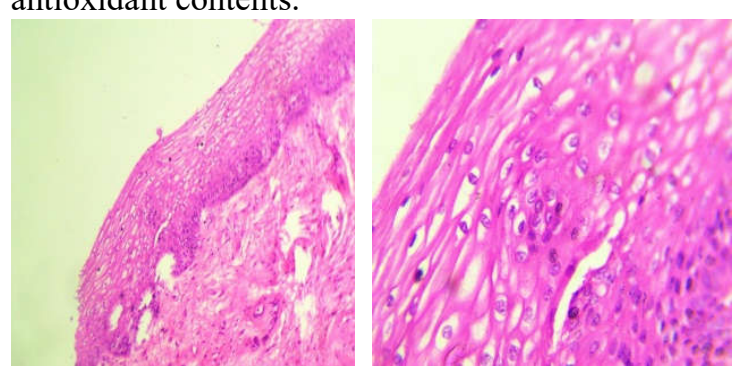

Plate 1: CIN-1 x10, and x40. Sections showing dysplastic squamous epithelial cells involving the lower third of the ecto cervix.

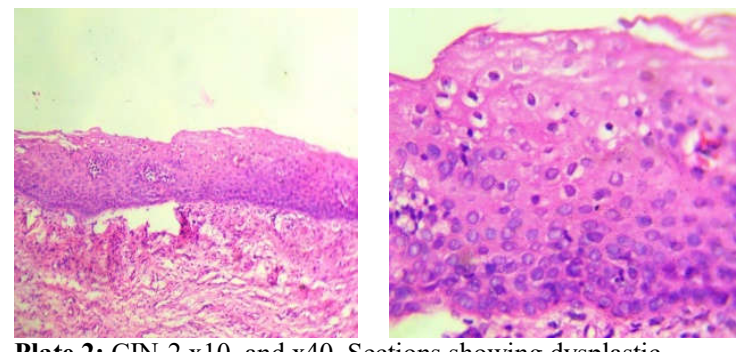

Plate 2: CIN-2 x10, and x40. Sections showing dysplastic squamous epithelial cells involving the lower two-thirds of the ecto cervix
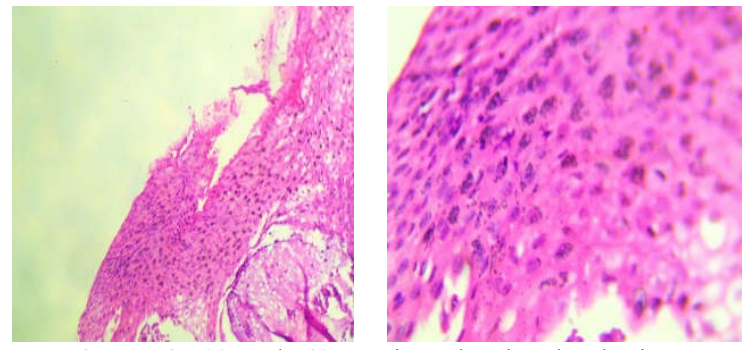

Plate 3: CIN-3 x10, and x40. Sections showing dysplastic squamous epithelial cells involving the full thickness of the ecto cervix.

The level of Glutathione Peroxidase (GPx) increased in participants with stage $3 \mathrm{CIN}$ compared to those with stages 1 and 2 CIN respectively. The serum GPx status in the control group however, was statistically the same for the CIN 1 and CIN 2 participants. In the study of Kim and coworkers, (2003) serum glutathione peroxidase (GPx) activity was significantly lower in patients with CIN than controls. The contrasting observation between our study and that of Kim et al. 2003 may be due to the difference in genetics and geographic locations of the study population.

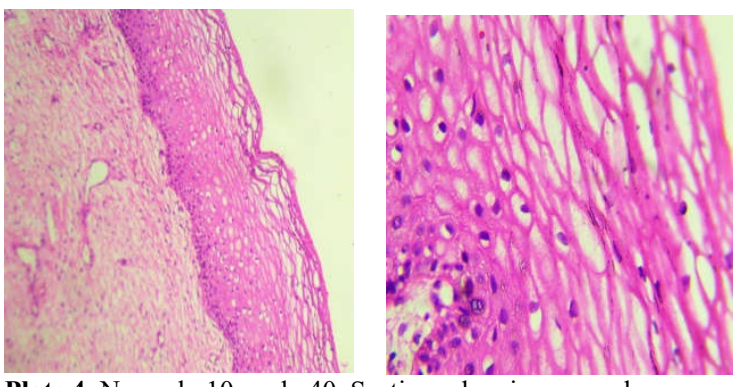

Plate 4: Normal x10, and $x 40$. Sections showing normal squamous epithelial cells lining the ectocervix.

Results from the study of Jelic et al., 2018 showed that SOD activity in serum was increased in all examined patient groups compared to healthy subjects, with statistical significance for patients in the advanced cervical cancer group. In the present study, the unhealthy participants were in the premalignant stage of the disease which may have been the reason for the insignificant difference between the serum SOD in $\mathrm{CIN}$ and control groups. Another research by (Cho et $a l ., 2009)$ reported significant decreased serum levels of antioxidant micronutrients, such as b-carotene, lycopene, zeaxanthin plus lutein, retinol, a-tocopherol, and g-tocopherol in patients with CIN. These micronutrients were probably in high demand by the premalignant cells. This micronutrient decrease is similar to that observed in serum $\mathrm{Cu}$ level of participants with a positive history of smoking in the CIN group of the present study.

A previous study that investigated serum lipid peroxidation, antioxidant capacity, and trace element levels in Korean women as related to uterine cervical neoplasia, reported that a significantly lower zinc $(\mathrm{Zn})$ levels and higher copper/zinc ratios were found in both $\mathrm{CIN}$ and cancer patients compared with the controls (Kim et al., 2003). The present study presented a contradicting pattern among the Nigerian women sampled that did not have history of smoking. There was no significant difference in serum $\mathrm{Zn}$ levels of women in the CIN and control groups (see Table 2). $\mathrm{The} \mathrm{Cu} / \mathrm{Zn}$ ratio in this study was low $(<0.5)$ for both the CIN and healthy individuals. Although among the women with a positive history of smoking, $\mathrm{Cu}$ levels were significantly higher in the control group than in the CIN group (Table 4).

It is relevant to state that the relationship of nutritional elements with cervical neoplasia has been reported to be complex by its multifactorial etiology, with many of the acknowledged risk factors being correlated with nutritional and socioeconomic standing. (Potischman and Brinton, 1996). Though, going by the Chi Square $\left(\mathrm{X}^{2}\right)$ presentation in Table 1 , all the parameters 
examined in the socio- demographic characteristics of the study population had p-values greater than 0.05 . An indication that the distribution between the control and CIN groups within each of the categories were not subjective. This means that the observed and expected were basically the same based on their proportionalities.

Serum $\mathrm{Mg}$ levels in this study were statistically not different in the control and CIN groups evaluated. This observation is different from the report from a study to compare serum $\mathrm{Mg}$ levels in women with breast cancer in Benin City, Nigeria (Atoe et al., 2014). In the just mentioned study, results showed a significant reduction in serum $\mathrm{Mg}$ levels of patients with breast cancer compared with those without the disease. The reason for basically same level of $\mathrm{Mg}$ in healthy and CIN patients observed may be because the disease is still in its precancerous state and the systems $\mathrm{Mg}$ level or supply was not yet depleted. This study suggests that serum $\mathrm{Cu}$ is easily used up in CIN patients with positive history of smoking than in patients without a smoking history. This buttresses that smoking is a major risk factor in cervical intraepithelial neoplasia.

Conclusion: The relevance of antioxidant status and nutritional elements in cervical neoplasia has been reported in this study. This is even more necessary particularly given the role they both play in estimating the oxidative defense capacities of patients at various stages of Cervical Intraepithelial Neoplasia. Proper lifestyle changes are also very important as a significant correlation between smoking and serum $\mathrm{Cu}$ was established. Serum $\mathrm{Cu}$ is of high demand by the premalignant cell metabolism of patients with a history of smoking.

\section{REFERENCES}

Aebi, H. (1984). Catalase in vitro. Methods Enzymology, 105: 121-126.

Atoe, K., Idemudia, O. and Eboreime, O. (2014). Serum magnesium levels in women with breast cancer in Benin City, Nigeria. International journal of tropical diseases and health, 4(6): 723728.

Bais, A. G., Beckmann, I., Lindemans, J., Ewing, P. C., Meijer, C. J., Snijders, P. J. F. and Helmerhorst, T. J. M. (2005). A shift to a peripheral Th2-type cytokine pattern during the carcinogenesis of cervical cancer becomes manifest in CIN III lesions. Journal of Clinical Pathology, 58:1096-1100. doi: 10.1136/jcp.2004.025072
Cho, H., Kim, M. K., Lee, J. K., Son, S. K., Lee, K., Lee, J. M., Lee, J. P., Hur, S. Y. and Kim, J. (2009). Relationship of serum antioxidant micronutrients and sociodemographic factors to cervical neoplasia: a case-control study. Clinical Chemistry Lab Med, 47 (8):1005-1012

Garcia-Closas, R., Castellsague, X., Bosch, X., Gonzalez, C. A. (2005). The role of diet and nutrition in cervical carcinogenesis: A review of recent evidence. International Journal Cancer; 117: $629-637$.

Henry, J. B. 1984. Clinical Diagnosis and Management. 17th edition. W.B Sander Co. Philadelphia. $157 \mathrm{p}$.

Jelic, M., Mandic, A., Kladar, N., Sudji, J., Božin, B. and Srdjenovic, B. (2018). Lipid peroxidation, antioxidative defense and level of 8-hydroxy-2deoxyguanosine in cervical cancer patients. $J$. Med. Biochem. 37(3): 336-345.

Kim, J. W., Choi, E. K., Lim, J. H., Kim, Y. T., Kim, D. K., Lee-Kim, Y. C., Kim, S. Y. and Chung, H. Y. (2002). Antioxidant system and oxidative stress in cervical cancer of Korean women. Korean J. Obstetrics Gynecology 45:51- 145.

Kim, S. Y., Kim, W. J., Ko, Y. S., Koo, J. E., Chung, H. Y. and Lee-Kim, Y. C.(2003). Changes in lipid peroxidation and antioxidant trace elements in serum of women with cervical intraepithelial neoplasia and invasive cancer, Nutrition and Cancer, 47(2):126-130.

Kumaraguruparan, R., Subapriya, R., Viswanathan, P., Nagini, S. (2002). Tissue lipid peroxidation and antioxidant status in patients with adenocarcinoma of the breast. Clinical Chim Acta, 325(1-2):165.

Lee, G. J., Chung, H. W., Lee, K. H. and Ahn, H. S. (2005). Antioxidant vitamins and lipid peroxidation in patients with cervical intraepithelial neoplasia. Journal of Korean Medical Science, 20 (2):267.

Magnani, L., Eaydou, M. and Jean, C. H. (2000). Spectrophotometric measurement of antioxidant properties of flavones and flavonols against superoxide anion, Anal. chim. Acta, 411: (1-2) 1: 209-216.

Marklund, S and Marklund, G. (1974). Involvement of the superoxide anion radical in the autoxidation of pyrogallol and a convenient assay for superoxide 
dismutase. European Journal of Biochemistry, 47: $469-474$.

Michels, K. B., Holmberg, L., Bergkvist, L., Ljung, H., Bruce, A. and Wolk, A. (2001). Dietary antioxidant vitamins, retinol and breast cancer incidence in a cohort of Swedish women. Inter. J. Cancer, 91: 7- 563.

Munoz, N., Franceschi, S., Bosetti, C., Moreno, V., Herrero, R., Smith, J. S., Shah, K. V., Meijer, C. J., Bosch, F. X. (2002). Role of parity and human papillomavirus in cervical cancer: The IARC multicentric case-control study. Lancet, 359: 101 $-1093$.

Parkin, D. M. (2001). Global cancer statistics in the year 2000. Lancet Oncology, 2: 43- 533.

Potischman N. and Brinton LA. (1996). Nutrition and cervical neoplasia. Cancer Causes Control, 7: 26 $-113$.

Shannon, J., Thomas, D. B., Ray, R. M., Kestin, M., Koetsawang, A., Koetsawang, S., Chitnarong, K., Kiviat, N., Kuypers, J. (2002). Dietary risk factors for invasive and in-situ cervical carcinomas in Bangkok, Thailand. Cancer Causes Control, 13: 9-691.

Singh, M., Dwivedi, S., Singh, G. and Bajpai, M. (1990). Serum copper levels in different stages of carcinoma. Indian J. Maternal Child Health, 1(1): $4-12$.

Smita, M., Naidu, K., Suryakar, A. N., Swami, S. C., Katkam, R. V. and Kumbar, K. M. (2007). Oxidative stress and antioxidant status in cervical cancer patients. Indian J. Clinical Biochemistry, 22 (2): 140-144.
Tomita, L.Y., Filho, A. L., Costa, M. C., Andreoli, M. A. A., Villa, L. L., Franco, E. L. and Cardoso, M. A. (2010). Diet and serum micronutrients in relation to cervical neoplasia and cancer among low-income Brazilian women. Inter. J. Cancer: 126: 703-714.

vanDam, P. A, Rolfo, C., Ruiz, R., et al. (2018). Potential new biomarkers for squamous carcinoma of the uterine cervix. ESMO Open, 3:e00352. Doi: 10.1136/ esmoopen-2018000352

Walboomers, J. M., Jacobs, M. V., Manos, M. M., Bosch, F. X., Kummer, J. A., Shah, K. V., Snijders, P. J., Peto, J., Meijer, C. J., Munoz, N. (1999). Human papillomavirus is a necessary cause of invasive cervical cancer worldwide. $J$. Pathology, 189: 9 - 12.

Wideroff, L., Potischman, N., Glass, A. G., Greer, C. E., Manos, M. M., Scott, D. R., Burk, R. D., Sherman, M. E., Wacholder, S. and Schiffman, M. (1998). A nested case-control study of dietary factors and the risk of incident cytological abnormalities of the cervix. Nutrition Cancer, 30: 6-130.

World Health Organization (2002). Diet, nutrition and prevention of chronic diseases. Technical report series, No 916. Geneva

Wozniak, B., Mila-Kierzenkowska, C., KedzioraKorna T. K., Drewa, T., Drewa, G. and Wozniak, A. (2007). Influence of the management of cervical carcinoma on the activity of catalase and glutathione peroxidase in erythrocytes. European J. Gynecology and Oncology, 28(6): 461- 466.

Ziegler, R. G. (1991). Vegetables, fruits, and carotenoids and the risk of cancer. American $J$. Clinical Nutrition, 53: 9S- 251S. 